\title{
Cytogenetic variability in species of genus Chironomus (Dip- tera, Chironomidae) from Poland
}

\author{
Paraskeva Michailova ${ }^{1 *}$, Elżbieta Warcha£owska-Ślima ${ }^{2}$, Boris Krastanov $^{1}$ and \\ ANDRZEJ KownACKI ${ }^{3}$ \\ ${ }^{1}$ Institute of Zoology, Bulgarian Academy of Sciences, blv. Tzar Osvoboditel 1, 1000 Sofia, Bulgaria. \\ ${ }^{2}$ Institute of Systematics and Evolution of Animals, Polish Academy of Sciences, str. Slawkowska 17, $31-016$ Kra- \\ kow, Poland. \\ ${ }^{3}$ Karol Starmach Institute of Freshwater Biology, Polish Academy of Sciences, str. Slawkowska 17, 31 - 016 Kra- \\ kow, Poland.
}

\begin{abstract}
Chromosome variability was analyzed in three Chironomus species: Chironomus plumosus L., Chironomus muratensis RySER, SCHOLL \& WulKeR, and Chironomus annularius MeIgen, from the natural populations in Poland. A comparative analysis of band sequences with other Palearctic populations was done. Chromosome band sequences of C. plumosus and C. muratensis did not differ from other Palearctic populations. A new homozygous band sequence was discovered in C. annularius. The ten sequences observed in the Polish populations of C. plumosus were represented in all cytogenetically studied European populations of this species. However, these sequences showed substantial interpopulational variation and they didn't demonstrate any geographical gradient. Some of the inversions in C. plumosus and C. annularius were also involved in the function of the so-called polymorphic system. The sensitivity of important chromosome structures (BRs and NOR) in the polytene chromosomes of $C$. annularius to organic contaminants in the studied area was presented. The morphology of the additional " $\mathrm{B}$ " chromosome found in C.plumosus can vary in different salivary gland cells. The existence of the "B" chromosome in the C. plumosus genome was considered in the light of its selective value in the studied area.
\end{abstract}

Key words: aberrations, additional "B” chromosome, Chironomus, polymorphic system, polytene chromosomes.

\section{INTRODUCTION}

The karyotype and chromosome variability of widely distributed, Palearctic Chironomid species have been studied extensively (KEYL 1962; Michailova 1989; KiKNAdZe et al. 1991a, 1996; Butler et al. 1999; Golygina and Kiknadze 2001). A detailed cytogenetic analysis of salivary gland chromosomes revealed the existence of sibling species in different Palearctic populations of the genus Chironomus (Keyl 1962; Ryser et al. 1983; Kerkis et al. 1988, 1989; Michailova 1989; KiKNADZE et al. 1991a, 1996). Also, the evaluation of chromosome polymorphism in natural populations of Chironomid species has contributed data on adaptation, cytogenetic differentiation and karyotype divergence of this genus (Petrova 1991; Kiknadze et al. 1998; BUTLER et al. 1999; Gunderina et al.1999). That's way the knowledge

\footnotetext{
* Corresponding author: phone: ++359 298851 15; fax: ++ 35998828 97; e-mail: michailova@zoology.bas.bg
}

of chromosome variability among the Chironomid populations is essential. However, information on the karyotype and chromosome polymorphism of the Chironomus species in Poland is very scarce. Only one study, reporting the presence of several cytotaxonomic species of the genus Chironomus (Michailova et al. 2002), is available in spite of the fact that this genus is very common in different aquatic biotopes (KownACKI 1999).

The present paper contributes information on polytene chromosomes and their cytogenetic variability in three Chironomus species: Chironomus plumosus L., Chironomus muratensis RYser, SCHOll \& Wulker and Chironomus annularius Meigen. These species belong to the cytocomplex "thummi" with chromosome arm combinations: AB CD EF G (Michailova 1989). Two of them (C. plumosus and C. muratensis) are closely related and are incorporated in the chromosome group "plumosus", while the third (C. annularius) is a single representative of the cytocomplex "thummi". Cytogenetic data concerning C. plumosus and $C$. annularius provide information on 
chromosome polymorphism and the process of microdifferentiation in C. plumosus. Genome polymorphism of $C$. plumosus is also discussed. Additionally, we compared our results of chromosome variability of C.plumosus with information of its cytogenetic variability in different Palearctic populations (Gunderina et al. 1999; Golygina and KiKnADZE 2001).

\section{MATERIALS AND METHODS}

Twenty three specimens of Chironomus plumosus and three specimens of $C$. muratensis were collected during May/June 2002 from a post-exploitation gravel pit in Rybnik, located in the Vistula Valley, $15 \mathrm{~km}$ south from Torun (northern Poland). A lake was formed after the pit was filled with subterranean water. It is characterized by a maximum depth of more than $5 \mathrm{~m}$, an area of $8 \mathrm{ha}$, sand-mud bottom, a water volume of $240000 \mathrm{~m}^{3}$, high alkaline reaction $(\mathrm{pH}=8,9)$, moderate conductivity $(400 \mu \mathrm{S} / \mathrm{cm})$, and biochemical oxygen demand $\left(\mathrm{BOD}_{5}\right)-4.79 \mathrm{mg} / \mathrm{dm}^{3}$. The lake is surrounded by forest with the exception of its southern bank, which is farmland.

Twenty one specimens of $C$. annularius were obtained during June 2002 from a retention pond of a sugar factory in Chybie (southern Poland). Michailova et al. (2001) gave information about the water quality of this pond. Oxidation was elevated in this water body, and $\mathrm{NH}_{2}, \mathrm{PO}_{4}$, and $\mathrm{N}$ $\mathrm{NO}_{3}$ ions were highly concentrated.

Larvae were fixed in a solution of $96^{\circ} \mathrm{C}$ ethanol and glacial acetic acid (3:1). Cytogenetic and morphological preparations were obtained from each larva. Isolated salivary glands were squashed for polytene chromosome preparations using a routine aceto - orcein method (Michailova 1989). Freezing in liquid nitrogen for removal of cover slips did permanent slides. After several steps in alcohol and xylene, they were remounted in Euparal. Larval head capsules and bodies were mounted in Euparal for morphological analysis. Slides of polytene chromosomes and larval morphology were deposited at the Institute of Zoology, Sofia - Bulgarian Academy of Sciences.

Polytene chromosomes of $C$. plumosus were identified by applying the maps of BUTLER et al. (1999), Gunderina et al. (1999), Golygina and KIKNADZE (2001). The polytene chromosomes of C. muratensis were identified by comparing with the literature (KiKNADZE et al. 1991a; Michailova et al. 2002). For a subsequent, detailed karyotype analysis of C. annularius, standard chromosome maps done by Keyl and Keyl (1959); KeYL (1962); Petrova and Michailova (1986), and Kiknadze et al. (1991a, 1996) were used. Sequences occurring in our species were symbolized according to KIKNADZE et al. (1991a, 1996) and Golygina and Kiknadze (2001) - for instance, homozygous states of arms: A - A1.1 or A2.2. BB1.1or B2.2 etc.; heterozygous states: A1.2, B1.2 and etc.

Inverted and standard band sequences were considered as alleles and their frequencies were estimated according to BUTLER et al. (1999). This permits the calculation of cytogenetic distance between Polish and other Palearctic populations by applying Nei's method (NEI 1972). A dendogram was made using UPGMA cluster analysis (SNEATH and SOKAL 1973) with PHYLIP (FELSENSTEIN 1993). Heterozygote frequencies of C.plumosus were tested for confirming to expectation under Hardy - Weinberg equilibrium using $\mathrm{X}^{2}$ test.

\section{RESULTS}

On the basis of external larvae morphology the samples were divided into three forms (A, B, C). Form $\mathrm{A}$ has a long tubule located ventrally and was therefore called the "plumosus" type; form C with a ventral short tubule - "semireductus" type, while form B exhibits an intermediate state between the two forms. Ollik and ZBikowski (2002) also differentiated the $\mathrm{C}$ form on the basis of length of the body of the larva as well as on the size of the head capsule.

Cytogenetically, the studied material was considered as three species: C. plumosus, C. muratensis and C.anmularius. Every species has specific chromosome markers by which the species were differentiated. They belong to cytocomplex "thummi" with chromosome arm combinations: AB CD EF G.

Chironomus plumosus L. - It has $2 \mathrm{n}=8$. Chromosomes $\mathrm{AB}$ and $\mathrm{CD}$ are metacentric, chromosome $\mathrm{EF}$ is submetacentric and chromosome $\mathrm{G}$ is telocentric.Chromosome $G$ has a nucleolar organizer $(\mathrm{NOR})$ and two Balbiani rings $\left(\mathrm{BR}_{2}, \mathrm{BR}_{3}\right)$. One Balbiani ring $\left(\mathrm{BR}_{1}\right)$ is located in arm B. (Figs. 1a, b, 2a, b, 3a, b, c).

Chromosome arms A, B, C, D are very polymorphic. It is interesting to note that on these arms the standard band sequences were converted into another homozygous band sequences through 


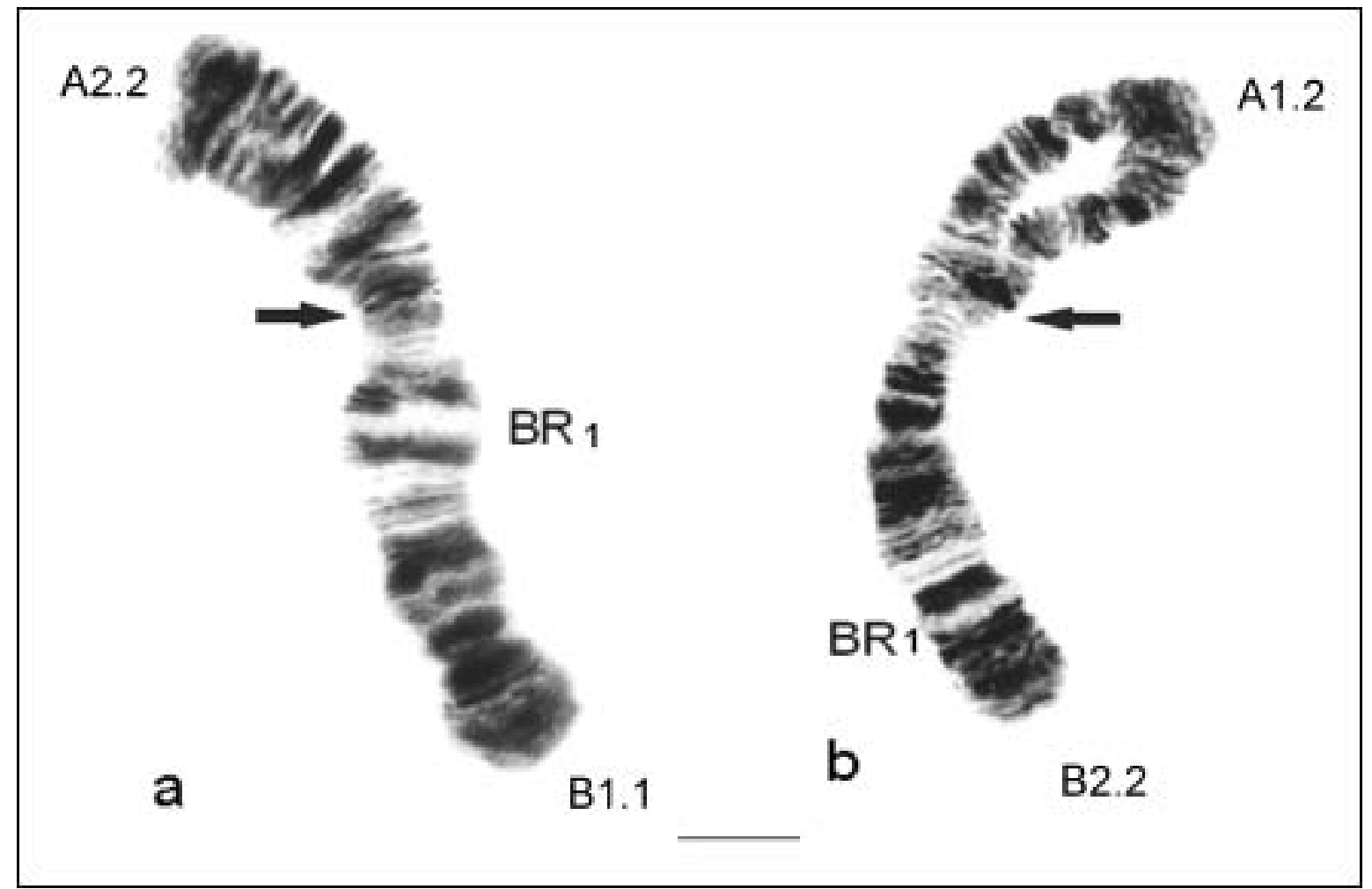

Fig. 1 - Polytene chromosomes of Chironomus plumosus L. a. Chromosome AB (Chromosome arm A with inverted homozygous sequences - A2.2; Chromosome arm B with standard sequences - B1.1); The centromere regions expressed by thin band. b. Chromosome AB (Chromosome arm A with inverted heterozygous sequences - A1.2; Chromosome arm B with inverted homozygous sequences - B2.2); The centromere region in heterozygous state; $\downarrow$ centromere region; BR - Balbiani ring; Bar $=10 \mu \mathrm{m}$.

heterozygotization (Table 1 and table 2) (Fig.1a, b). In arms A and B standard and inverted band sequences occurred almost in the same frequency (Table 2). In arms C, D the standard sequences (C1, D1) were predominated (Table 2) (Fig. 2b). The heterozygous (C1.2) and homozygous inversions (C2.2, D2.2) appeared very rarely (Table 1) (Fig.2a). The arms E, F and G have the standard band sequences (Table 1 and table 2) (Fig.3a, b, c). In a mosaic state an asysnapsis was found in chromosome arms $\mathrm{E}$ and $\mathrm{F}$ (Fig. 3a, b).

$\mathrm{BR}_{1}$ in arm $\mathrm{B}$ occurred in a very active state in all studied individuals, although not in all cells.

The studied individuals differed with respect of their centromeric heterochromatin In some specimens (about 50\%) centromere regions of the polytene chromosomes were represented by well defined large heterochromatin blocks (Figs. 2b, $3 b)$. In five individuals, in few cells the centromere heterochromatin in chromosomes $\mathrm{AB}, \mathrm{CD}$ and $\mathrm{EF}$ appeared in a heterozygous state (Figs. 1b, 3b).

Four individuals have a "B" chromosome, which appeared in a compact as well as in a network state (Fig. 4 a, b). Every type is observed in
Table 1 - Types and frequency of chromosome inversions of $C$. plumosus.

\begin{tabular}{ccc}
\hline $\begin{array}{c}\text { Inversion } \\
\text { sequences }\end{array}$ & Frequency & $\chi^{2}$ \\
\hline $\mathrm{A} 1.1$ & 0.348 & \\
$\mathrm{~A} 1.2$ & 0.304 & 3.52 \\
$\mathrm{~A} 2.2$ & 0.348 & \\
$\mathrm{~B} 1.1$ & 0.435 & \\
$\mathrm{~B} 1.2$ & 0.217 & $7.25^{*}$ \\
$\mathrm{~B} 2.2$ & 0.348 & \\
$\mathrm{C} 1.1$ & 0.826 & \\
$\mathrm{C} 1.2$ & 0.130 & \\
$\mathrm{C} 2.2$ & 0.044 & \\
$\mathrm{D} 1.1$ & 0.522 & \\
$\mathrm{D} 1.2$ & 0.304 & \\
$\mathrm{D} 2.2$ & 0.174 & 0 \\
$\mathrm{E} 1.1$ & 1.000 & 0 \\
$\mathrm{~F} 1.1$ & 1.000 & 0 \\
$\mathrm{G} 1.1$ & 1.000 & \\
\hline$* \mathrm{P}<0.01$ & & \\
\hline
\end{tabular}

different individuals and within the salivary gland cells of an individual. It doesn't have a clear banding structure and it is often oriented towards chromosome $\mathrm{G}$. 


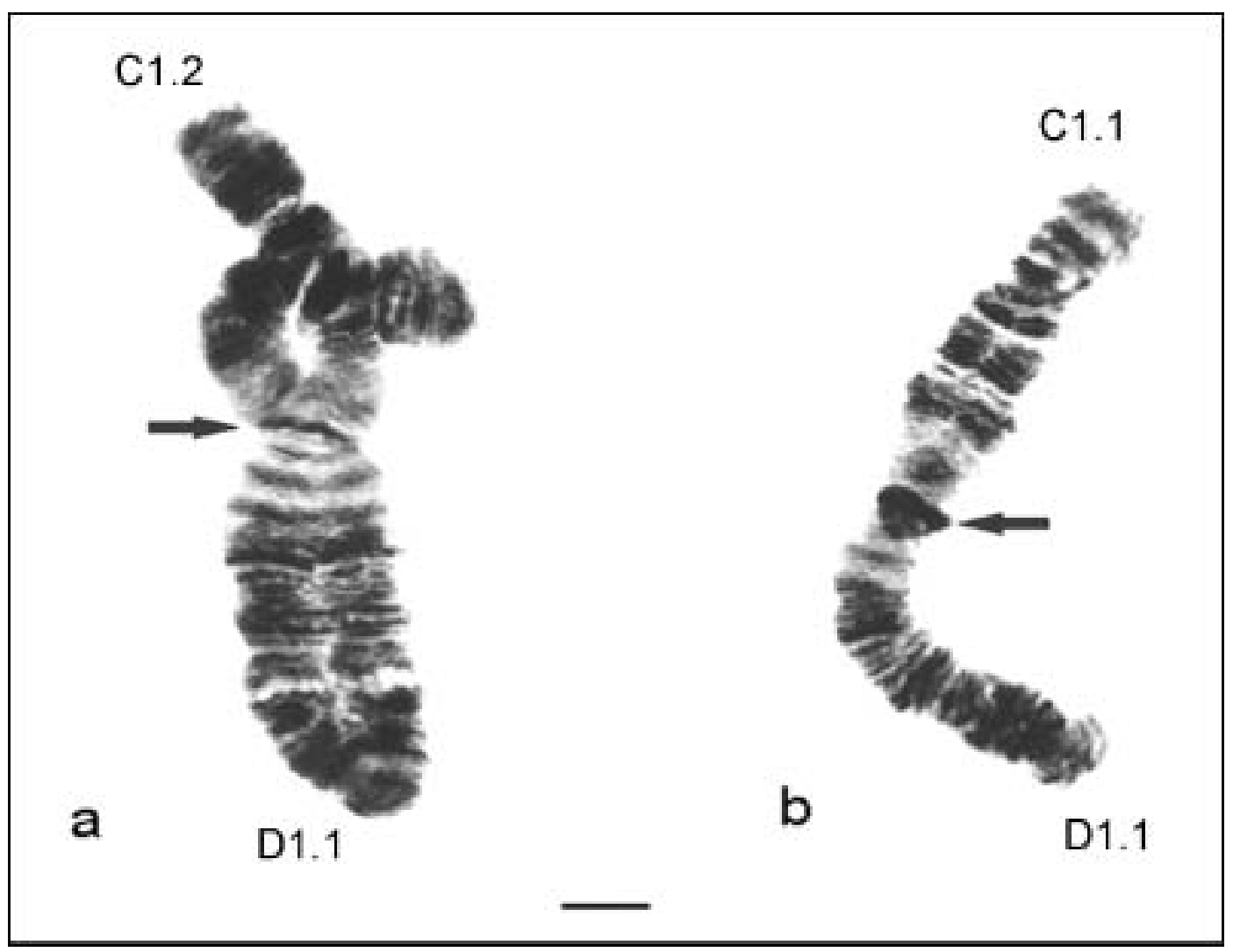

Fig. 2 - Polytene chromosomes of Chironomus plumosus L. a. Chromosome CD (Chromosome arm C, with inverted heterozygous sequence - C1.2; Chromosome arm D, with standard sequences - D1.1); The centromere regions expressed by thin band. b. Chromosome CD (Both arms are with standard sequences - C1.1 and D1.1); The centromere regions expressed by large heterochromatin block. $\downarrow$ centromere region; Bar $=10 \mu \mathrm{m}$.

Table 2 - Frequency of band sequences in polytene chromosomes of C. plumosus.

\begin{tabular}{cc}
\hline Band sequences & Frequency \\
\hline A1 & 0.500 \\
A2 & 0.500 \\
B1 & 0.543 \\
B2 & 0.457 \\
C1 & 0.891 \\
C2 & 0.109 \\
D1 & 0.674 \\
D2 & 0.326 \\
E1 & 1.000 \\
F1 & 1.000 \\
G1 & 1.000 \\
\hline
\end{tabular}

The studied population of C.plumosus had a high level of chromosome polymorphism - the larvae with heterozygous inversions were $87 \%$ and the average number of heterozygous inversions per larva was 0.87 .

Chironomus muratensis RYSER, SCHOLL \& WULKER. - Its chromosome complement is $2 \mathrm{n}=8$.
Chromosomes AB, CD are metacentric, chromosome $\mathrm{EF}$ is submetacentric and chromosome $\mathrm{G}$ is telocentric. There are two nucleolar organizers (NOR) in arms $\mathrm{C}$ and $\mathrm{G}$, and three Balbiani rings in arms $B\left(B_{1}\right)$ and $G\left(B_{2}, B_{3}\right)$ (Fig. 5 a, b, c, d). Arms A, C, E, F, G appeared in standard band sequences A1, C1, E1, F1 and G1 respectively. Arm B had an inverted band sequence B2, while arm D was in heterozygous and standard homozygous state (D1.2 and D1.1). The heterozygous state of this arm has been documented in Russia (Petrova and Michailova 1986; Kiknadze et al. 1991a), Finland (Michailova 2001), and Poland (Michailova et al. 2002).

Chironomus annularius Meigen - This species has $2 \mathrm{n}=8$. Chromosomes $\mathrm{AB}$ and $\mathrm{CD}$ are metacentric, chromosome EF is submentacentric, and chromosome $\mathrm{G}$ is telocentric. One Balbiani ring (BR) is located in arm $G$ and a nucleolar organizer (NOR) appears in arms A, C, E and G (Fig. 6a, b, c, d, e, f, g). 


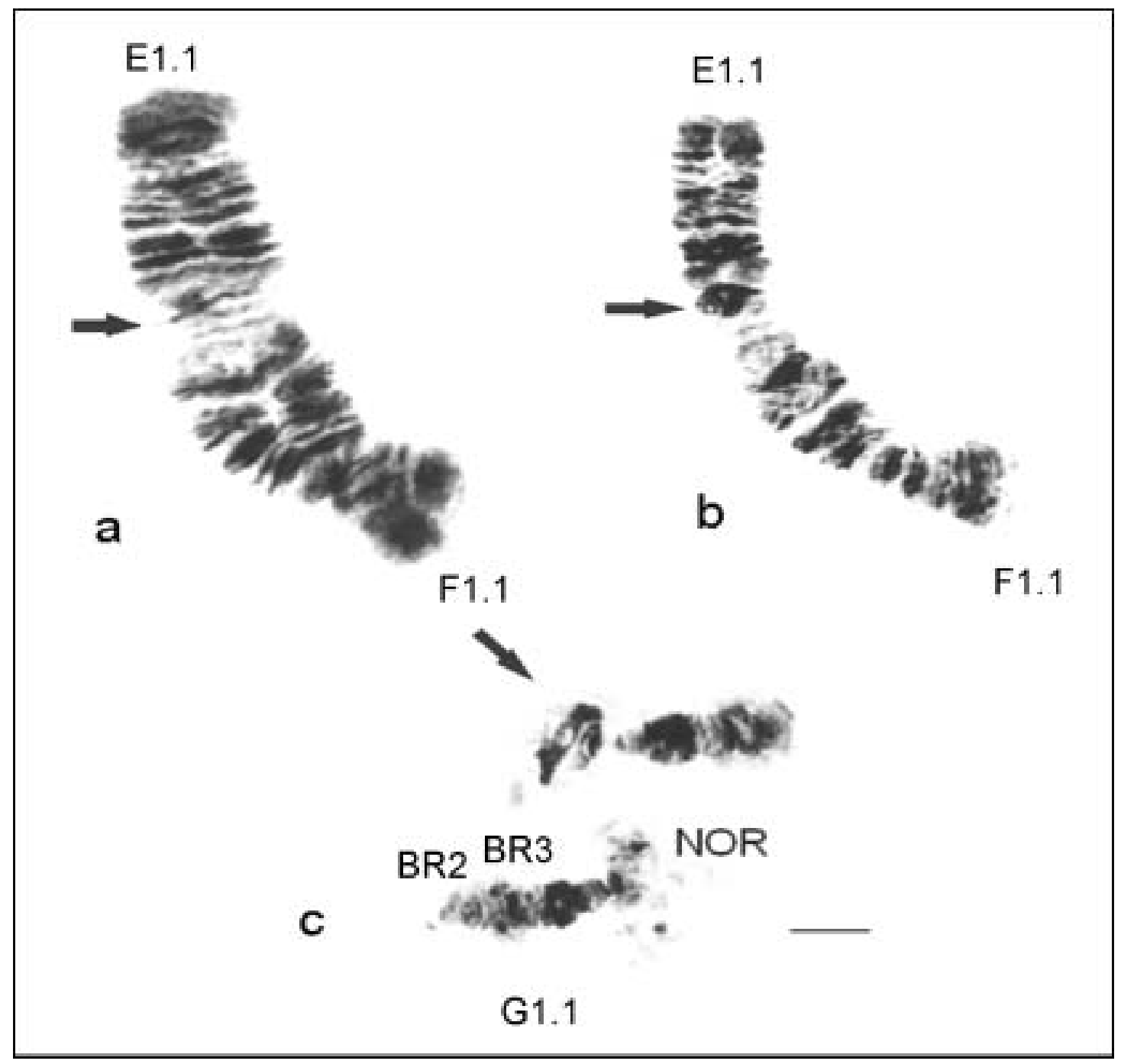

Fig. 3 - Polytene chromosomes of Chironomus plumosus L. a. Chromosome EF (Both arms have standard sequences - E1.1 and F1.1, with unpaired sections in arm F); The centromere regions expressed by thin band. c. Chromosome EF (Both arms are with standard sequences - E1.1 and F1.1, with unpaired arm E); The centromere regions expressed by large heterochromatin block. d. Chromosome $\mathrm{G}$ with standard sequences - G1.1, the both homologues are unpaired; The centromere regions expressed by large heterochromatin block. $\downarrow$ centromere region; BR - Balbiani ring; NOR - Nucleolar organizer; Bar $=10 \mu \mathrm{m}$.

Arm A has two band sequences (A1 and A2) (Table 4). They appeared in three states, standard A1.1 (Fig. 6 a) inverted homozygous state A2.2 (Fig. 6 c), and heterozygous state A1.2 (Fig.6 b). The nucleolar organizer (NOR) in this arm as well as in arm E was slightly expressed and in $10 \%$ of the individuals the NOR in arm A was in a heterozygous state.

In arm B has three band sequences: B1, B2 and a new one B4 (Table 4). From the standard, two steps of inversions have formed the new band sequence of arm B:

22212019 18a 18b $17 \mathbf{1 6} 151413$

$2221201918 \mathrm{a} 131415 \mathbf{1 6} \mathbf{1 7} \mathbf{1 8 b}$
22212019 18a $131415 \mathbf{1 8 b} 17 \mathbf{1 6}$ (the new homozygous band sequences) (the bold numbers were included in the inversions) (Fig. 6d). The standard band sequences of this arm were predominated (Table 3 and table 4).

With exception of $\operatorname{arm} \mathrm{D}$, the arms C, E, G appeared in standard homozygous state only (C1.1, E1.1, G1.1) (Fig.6e, f, g) (Table 3 and table 4). In $\operatorname{arm~F}$, standard band sequences F1 was predominated (Fig.6f). Only 3 individuals had a heterozygous inversion (F1.2). It is important to underline that in all studied individuals in the mosaic state, the homologues of chromosome $G$ were unpaired due to different functions of both homo- 


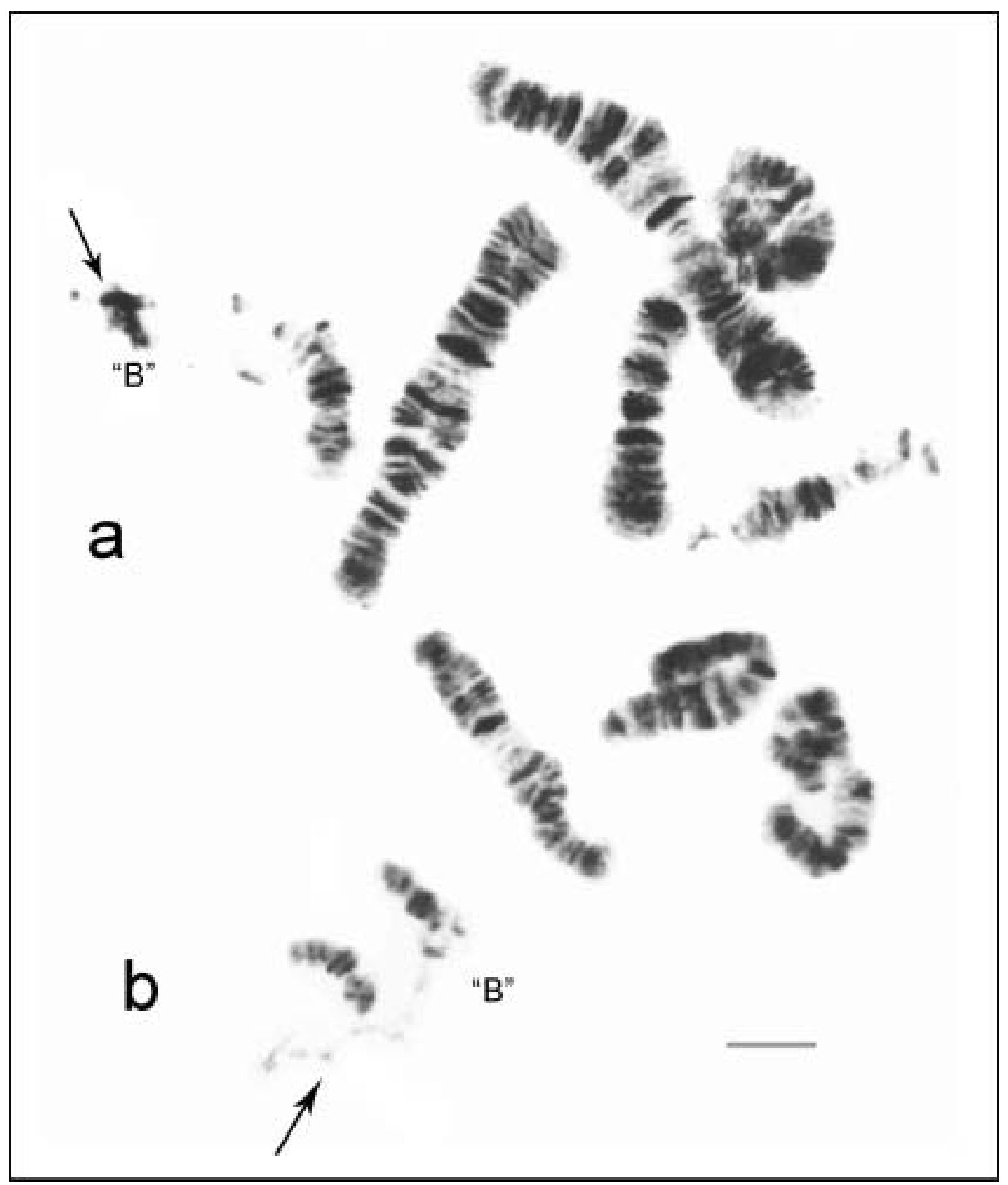

Fig. 4 - Chromosome "B" in Chironomus plumosus L. a. Compact chromosome "B"; b. Decondensed chromosome "B"; Bar $=10 \mu \mathrm{m}$.

logues. In C. annularius $61 \%$ of studied individuals were with heterozygous inversions. The average number of heterozygous inversions per larva was 0.71 .

\section{DISCUSSION}

A total of 24 and 15 band sequences were found in 30 Palearctic and several Nearctic popu- lations of C. plumosus, respectively (BUTLER et al. 1999; Gunderina et al. 1999). Eight were common for both Palearctic and Nearctic regions. Detailed cytogenetic and statistical analysis showed clear cytogenetic differentiation between Palearctic and Nearctic populations (BUTLER et al. 1999). On the other hand, Gunderina et al. (1999) documented considerable cytogenetic diversity in European and Asian (Siberian) populations of C. plu- 


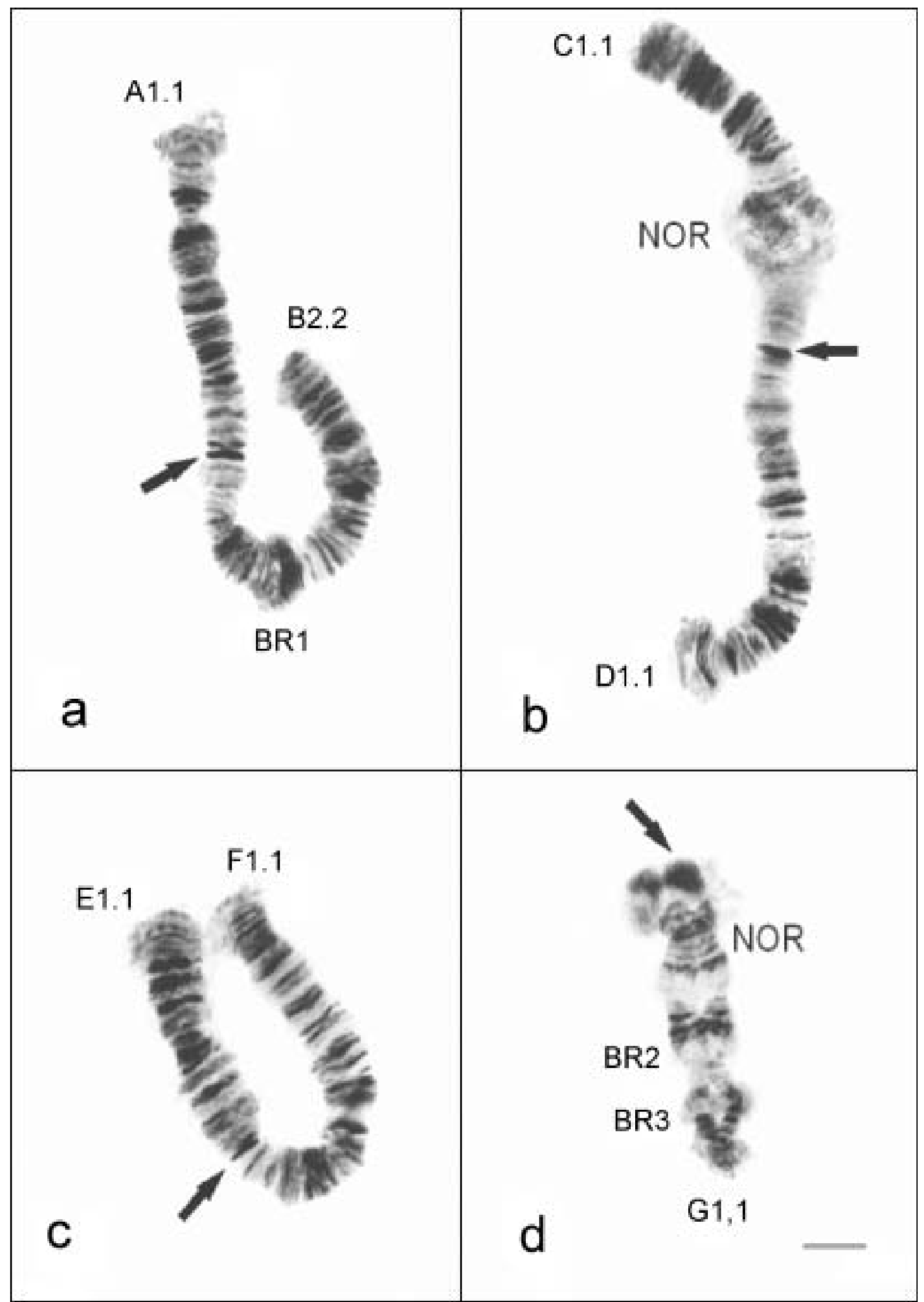

Fig. 5 - Polytene chromosomes of Chironomus muratensis Ryser, SCHOLl \& Wulker. a. Chromosome AB (Chromosome arm A with standard sequences - A1.1; Chromosome arm B with inverted homozygous sequences - B2.2); $b$. Chromosome CD (Both arms are with standard sequences - C1.1 and D1.1); c. Chromosome EF (Both arms are with standard sequences - E1.1 and F1.1); d. Chromosome G (with standard sequences - G1.1); $\downarrow$ centromere region; BR - Balbiani ring; NOR - Nucleolar organizer. Bar $=10 \mu \mathrm{m}$. 
Table 3 - Types and frequency of chromosome inversions of $C$. annularius.

\begin{tabular}{cc}
\hline Inversion sequences & Frequency \\
\hline A1.1 & 0.238 \\
A1.2 & 0.381 \\
A2.2 & 0.381 \\
B1.1 & 0.619 \\
B4.4 & 0.095 \\
B1.2 & 0.286 \\
C1.1 & 1.000 \\
D1.1 & 0.952 \\
E1.1 & 0.048 \\
F1.1 & 1.000 \\
F1.2 & 0.857 \\
G1.1 & 0.143 \\
\hline
\end{tabular}

Table 4 - Frequency of band sequences in polytene chromosomes of $C$. annularius.

\begin{tabular}{cc}
\hline Band sequences & Frequency \\
\hline A1 & 0.429 \\
A2 & 0.571 \\
B1 & 0.762 \\
B2 & 0.143 \\
B4 & 0.095 \\
C1 & 1.000 \\
D1 & 0.952 \\
D2 & 0.048 \\
E1 & 1.000 \\
F1 & 0.929 \\
F2 & 0.071 \\
\hline G1 & 1.000 \\
\hline
\end{tabular}

mosus, which form the Palearctic parts of its Holarctic range. These populations are distinguished by both the type and frequency of sequences. It is worth noting that an eastern population in Siberia (Yakutia, Beloe Lake) was the most cytogenetically divergent from other Palearctic populations (Butler et al. 1999). Also, Gunderina et al. (1999) underlined that in central Palearctic populations cytogenetic differences were not as substantial, although they increased toward the periphery of the range of $C$. plumosus. Sequences A1, A2, B1, B2, C1, D1, D2, E1, F1 and G1 found in the Polish population were represented in all European populations cytogenetically studied by GUNDERINA et al. (1999) and Butler et al. (1999). Some of these (A2, B1, B2, D2) have been recorded in the Nearctic. However, in the Nearctic populations the sequence $D_{2}$ occurred as the most frequent sequence in this region (BUTLER et al. 1999). Seven of the sequences found in the Polish population (A1, B1, C1, D1, E1, F1 and G1) are distributed in all Palearctic populations and are considered as the main common Palearctic se- quences (MCP) (Gunderina et al.1999). Therefore, concerning the band sequences, the Polish population of C. plumosus was not different from other Palearctic and some Nearctic populations. However, the sequence frequencies showed considerable inter population variation. The standard sequences of arms C (C1), D (D1), E (E1), F (F1) and $G(\mathrm{G} 1)$ predominated in Poland. However, the inverted homozygous state in arm A (A2.2) and arm B (B2.2) respectively, occurred in high frequencies. Even more, statistically significant deviations were observed in arm B. It is quite possible that the heterozygous state of this arm have some advantages in studied are, characterized by alkaline reaction and oxygen demand. These data confirm the idea done by Michailova and Petrova (1991) that inversions have varying selective priorities in different ecological conditions.

The dendrogram (Fig. 7) showed that the Palearctic populations of $C$. plumosus were clustered into several groups. C. plumosus from geographically close regions was separated into different clusters. For instance, samples from Altai lakes were put into different clusters. On the other hand, populations from geographically isolated sites were closely grouped together. The studied Polish population formed an independent group, which was most closely related to the Novosibirsk population (NSK-K), with the smallest cytogenetic distance 0, 0528 (Table 5). The highest cytogenetic distance exists between Poland and Volgograd $-\mathrm{Vu}$ populations - 0, 2165 (Table 5). The results confirmed Gunderina's et al. (1999) idea that there isn't any geographical gradient of the observed cytogenetic variability of the species. It is quite possible that in all these populations there are variations in the frequency of aberrations depending on the specific conditions of the habitat.

In the arms A, B, C, D of C.plumosus and in arm $A$ of $C$. annularius the polymorphic system, described by Michailova (1989) was evident one homozygous inversion converted into another homozygous state through heterozygotization. This polymorphic system has been found in $C$. plumosus from Hungary and Switzerland (Michailova and Fisher 1986), although it was first detected in C. annularius. It is quite possible that each chromosome band sequence has some advantage in a specific ecological niche available to a population. It is worth underlining that the standard sequences of arms C, D, E, F of C. plumosus predominated, while in C.plumosus and in C. annularius inverted homozygous (A2.2) and 


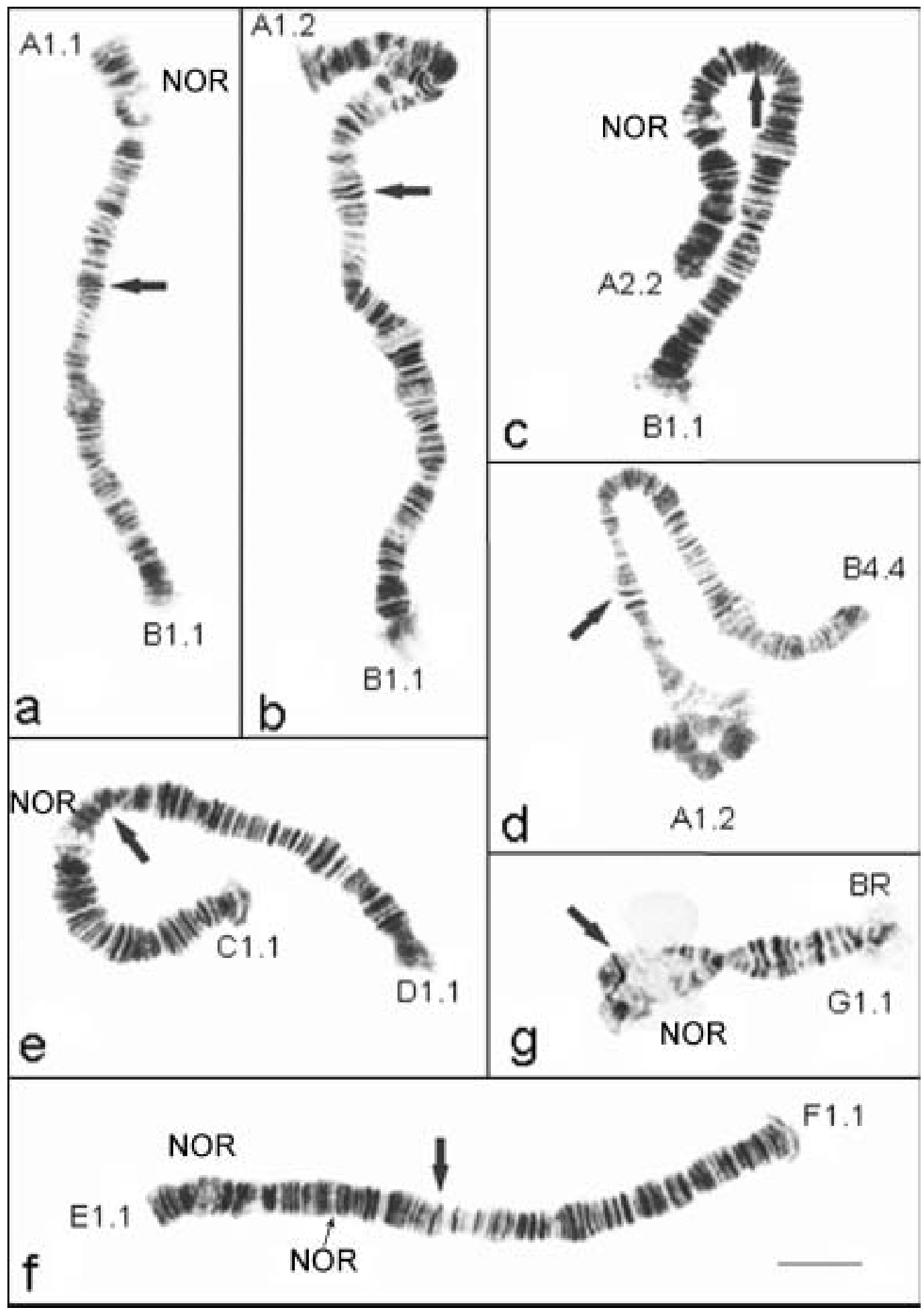

Fig. 6 - Polytene chromosomes of Chironomus annularius Meigen a. Chromosome AB (Both arms are with standard sequences - A1.1 and B1.1); b. Chromosome AB (Chromosome arm A with inverted heterozygous sequences A1.2. Chromosome arm B with standard sequence - B1.1); c. Chromosome AB (Chromosome arm A with inverted homozygous sequences - A2.2; Chromosome arm B with standard sequences - B1.1); d. Chromosome AB (Chromosome arm A with inverted heterozygous sequences - A1.2; chromosome arm B with new band sequences - B4.4); e. Chromosome CD (Both arms are with standard sequences - C1.1 and D1.1); f. Chromosome EF (Both arms are with standard sequences - E1.1 and F1.1); g. Chromosome G (with standard sequences - G1.1). $\downarrow$ centromere region; BR - Balbiani ring; NOR - Nucleolar organizer. Bar - $10 \mu \mathrm{m}$. 


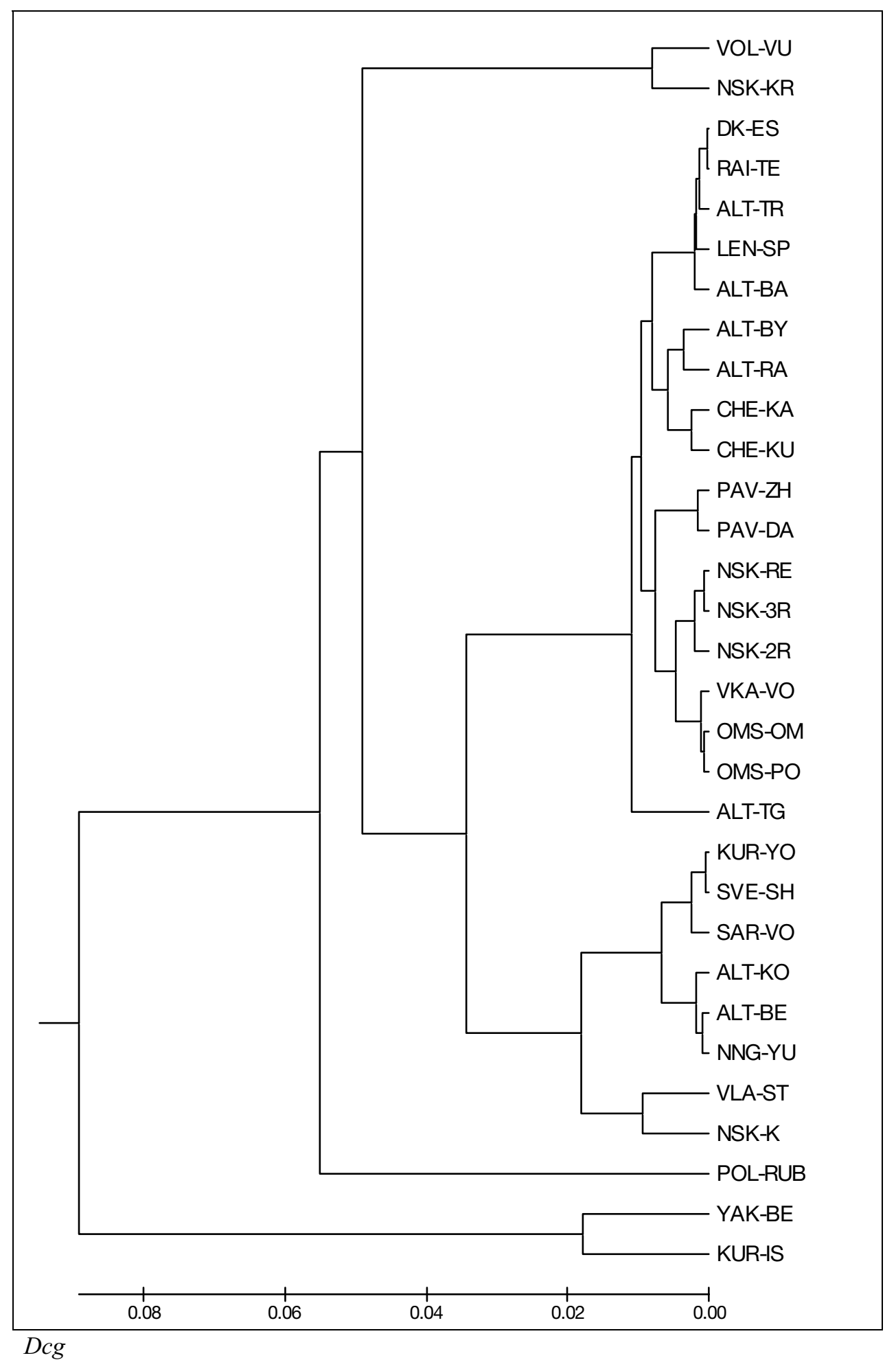

Fig. 7 - The dendrogram of C.plumosus showing the cytogenetic distance (Dcg) between Palearctic populations, studied by Golygina and Kiknadze (2001) and C.plumosus of Polish population (this study). The symbols indicated the region (the first symbol) and lake (the second symbol): DK - Denmark; RAI - Republic Altai; ALT - Altai; LEN - Leningrad; CHE - Chelyabinsk; PAV - Pavlovsk; NSK - Novosibirsk; VKA - East Kasachstan; OMS - Omsk; VLA - Vladimirovsk; NNG - Nijegorodsk; SAR - Saratov; SVE - Sverdlovsk; KUR - Kurgan; VOL - Volgograd; POL - Ryb. - Poland; YAK - Yakutia. The scale below the tree demonstrates the length of the tree branches in cytogenetic distances. 


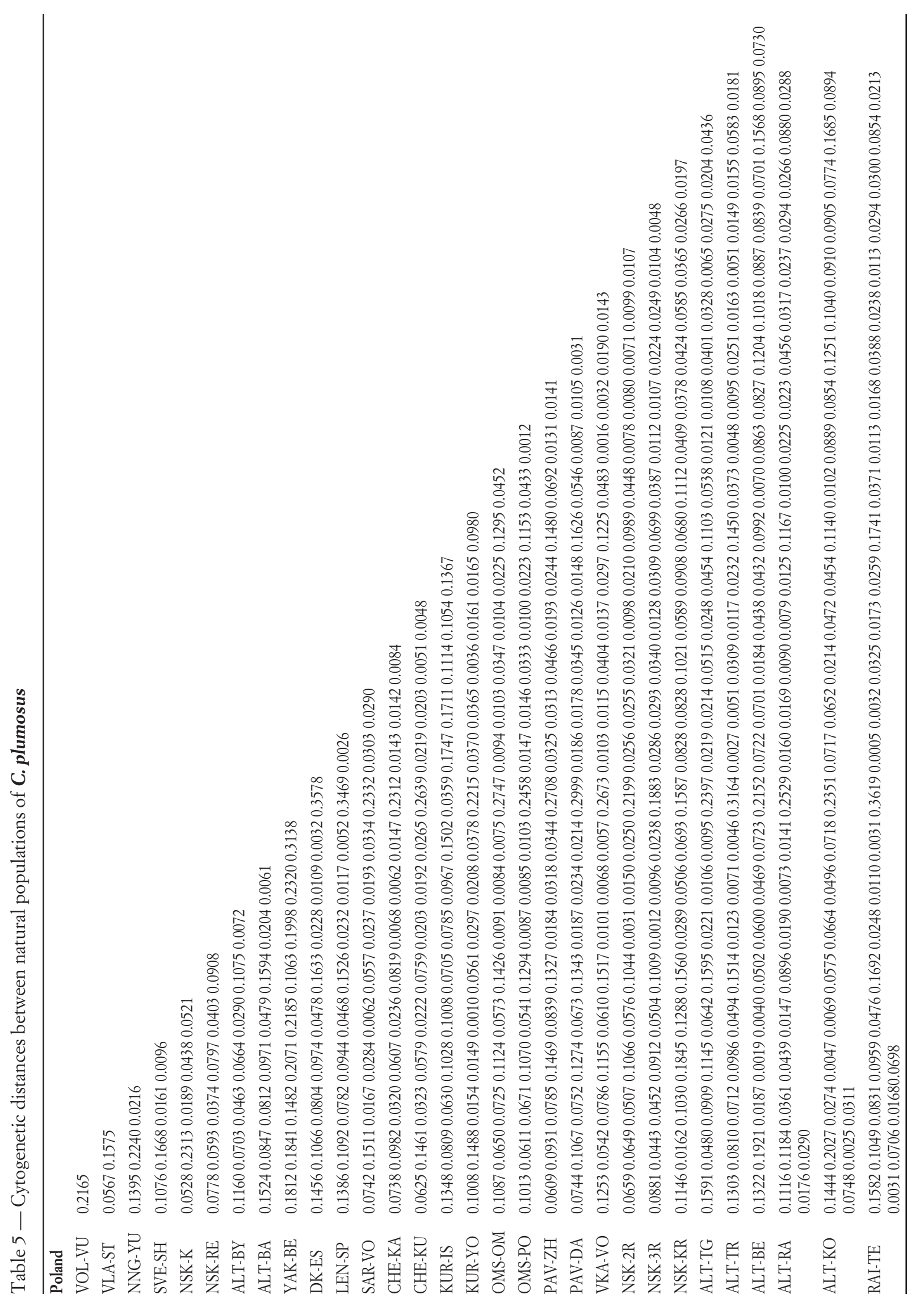


heterozygous (A1.2) states appeared almost in equal frequency. These results support PEDERSEN's (1978) idea that "polymorphism can be used as a biological system that very quickly records change in the environments". In both species the polymorphous system could be treated as an "adaptive population strategy" determined by the fluctuation of homo-and heterokaryotypes.

C. annularius also possesses substantial chromosome variability in its range. The standard banding patterns of arm A have been described only from Germany (KeYL and Keyl 1959), while heterozygous and inverted homozygous states have been observed in most populations in Germany (Keyl and Keyl 1959; Keyl 1962), Russia, Bulgaria, Hungary (Beljanina 1981; Kinnadze et al. 1996; Petrova and Michailova 1986) and Poland (Michailova et al. 2002). Also, in arm F heterozygotes have been found in these populations. Beljanina (1981) and Petrova and Michailova (1986) noted that microdifferentiation was occurring in Russian populations due to several fixed homozygous inversions in the karyotype of the species. In the studied area $C$. annularius was found in a water body characterized by an increased level of organic contaminants. In this area we observed a new homozygous inversion in arm B in a low frequency.

Interestingly, differences in the amount of centromeric heterochromatin of chromosomes were observed in C. plumosus. Differences in the quantity of heterochromatin show how this part of the genome evolves. Quantitative variation in heterochromatin among species is probably due to several mechanisms such as multiple replication, unequal exchange, amplification, accumulation and deletion (John 1988). Such differences have also been observed in other geographically isolated Palearctic populations of C.plumosus: as in Russia (Kiknadze et al. 1991b; Petrova 1991; Golygina and Kiknadze 2001), Hungry, Switzerland (Michailova and Fisher 1986), and Finland (Michailova 2001). Variation may arise from amplification events in centomeric heterochromatin and illustrates the process of cytogenetic differentiation. Molecular methods employed in the future will provide additional information on the evolution of this species. However, this cytogenetic mechanism is not yet involved in postmating isolation factors, which was proven by a hybridization test (Michailova and Fisher 1986).

C. annularius was found in a water body characterized by an increased level of organic contaminants (Michailova et al. 2001). Changes were observed in the functional activity of BRs in chromo- some $G$ and the nucleolar organizer (NOR) in chromosome arms A and E. The nucleolar organizer in chromosome $\mathrm{AB}$ is active in Russian (Kinnadze et al. 1991a, 1996) and other Polish populations (Michailova et al. 2002). Also, KiKNADZE et al. (1996) discerned several well-expressed Balbiani rings in chromosome $G$, which were not seen in our material. We observed only one slightly active $\mathrm{BR}$ in the telomeric region of chromosome G. Both structures (BRs and NOR) are very sensitive to different stress conditions and are used as a model to study the response of the genome to different environmental factors (DiEZ et al. 1990; Michailova et al. 1998). BRs are sites of intense gene transcription for silk proteins (WIESLANDER 1994), important for the construction of larval tubes. Obviously the BR system seems to be very sensitive to high levels of organic contaminants detected in this area by Michailova et al. (2001). Most BRs observed in Russian populations (KIKNADZE et al. 1996) were not seen in the studied area. Only one BR, located in the telomere region of chromosome $G$, appeared slightly active or in heterozygous state. Also, the nucleolar organizers (NOR) in arms A and E were suppressed or appeared in a heterozygous state, which might be due to the organic contaminants, established in the studied area. The NOR contains genes responsible for the synthesis of rRNA. Suppression is probably due to inhibition of RNA polymerase I (Horgen and GREFFIn 1971) or to the synthesis of highly conservative proteins (HSPs) which have a protective role in the cells (MuLtohoff et al. 1998). However, it is still unclear which mechanism is involved in the suppression of NOR activity. The same reaction was observed in natural populations of $C$. riparius in different anthropogenic sites (Michailova et al. 1996; 2000).

Different hypotheses on the evolutionary origin of "B" chromosomes have been proposed. The most widely accepted view is that they originated from A chromosomes because of homology between the two types (Самасно et al. 2000). The molecular cytogenetic characteristics of Chironomid "B" chromosome was studied by (SIIRIN et al. 2003). Applying in situ hybridization, these authors found that "B" chromosome are composed of repetitive DNA sequences homologous to sequences of centromere and telomere DNA of A chromosomes and also these of mobile elements NLRCth1. No ribosomal DNA repeats were identified in "B" chromosome. They postulated that "B" chromosome and chromosome $G$ have similar telomeric and centromeric organization which influence on their very repeated association. In 
the studied species (C. plumosus) "B" chromosome frequently pair with chromosome $\mathrm{G}$.

The polytene "B" chromosome has been established in different populations of $C$. plumosus (Keyl and Hagele 1971; Ilynskaja and Petrova 1985; Michailova and Mettinen 2000; Golygina and Kiknadze 2001). Ilinskaja and Petrova (1985); Michailova and Mettinen (2000) considered that "B" chromosome increased the chances of survival for individuals under extreme, polluted conditions and in this way proposed their selective value. " $B$ " chromosome was found by us in both groups of $C$. plumosus in the studied area, which is characterized by high alkaline reaction and oxygen demand.

Acknowledgements - This research was supported by a grant from an exchange program between the Bulgarian Academy of Sciences and the Polish Academy of Sciences. Thanks are due to Dr. L. Gunderina and Dr. V. Golygina (Novosibirsk), Institute for Cytology and Genetics for their useful suggesting the cluster analysis. The authors thank Dr. Ollik and Dr. Zbikowski for collecting some of the studied material.

\section{REFERENCES}

Beljanina S., 1981 - Comparative karyological characteristics of Chironomus annularius (Diptera, Chironomidae) from different geographical regions. Zool. Journal, 60: 1030-1039 (In Russian).

Butler M.G., Kiknadze I.I., Golygina V., Martin J., Istomina A., Wulker W., Subblette J. and Subblette M., 1999 - Cytogenetic differentiation between Palearctic and Nearctic populations of Chironomus plumosus L. (Diptera, Chironomidae). Genome, 42: 797-815.

Camacho J.P.M., Sharbel T.F. and Beukeboom L.W., $2000-B$ chromosome evolution.. Phil. Trans. R. Soc.Lond., 355: 163-178.

Diez L., Cortes E., Merimo J. and Santa-Cruz M., 1990 - Galactose induced puffing changes in Chironomus thummi: Balbiani rings and their dependence on protein synthesis. Chromosoma, 99: 61-70.

Felsenstein J., 1993 - Phylogeny Inference Package (PHILIP). Version 3.5 Seattle: Univ. of Washington.

Golygina V. and Kinnadze I.I., 2001 - Karyofund of Chironomus plumosus (Diptera, Chironomidae) in Palearctic. Tsitologya, 43: 507-519 (In Russian).

Gunderina L., Kiknadze I.I. and Golygina V., 1999 - Intraspecific differentiation of the cytogenetic structure in natural populations of Chironomus plumosus L., the central species in the group of sibling species (Chironomidae: Diptera). Russian J. Genetics, 35: 142-150.
Horgen P. and GrefFin D., 1971 - Specific inhibitors of the three RNA polymerases from the aquatic fungus Blastcadiella emersonni. Proc. Natl. Acad. Sci., USA 68: 338-341.

JoHn B., 1988 - The biology of beterochromatin. In: Verma, R.S. (ed). Cambridge Univ. Press, 1-147.

Ilynskaja N. and Petrova N., 1985 B-chromosomes of Chironomus plumosus (Diptera, Chironomidae). Genetika, 21; 1671-1679 (In Russian).

Kerkis I., Filippova M., Shobanov N., Gunderina L. and Kiknadze I.I., 1988 - Karyological and genetico-biochemical characteristics of Chironomus borokensis sp.n. from the plumosus group (Diptera, Chironomidae). Tsitologya 30: 1364-1372 (In Russian).

Kerkis I., Kiknadze I.I., Filippova M. and GundeRINA L., 1989 - Cytogenetic differentiation of the Chironomus species of the plumosus group. Advances in chironomidology. Part 1. Acta Biol. Debr. Oecol. Hung., 2: 103-114.

KeYl H., 1962 - Chromosome evolution bei Chironomus II. Chromosomenumbautenund phylogenetische Beziebungen der Arten. Chromosoma, 13: 496-541.

Keyl H and Hagele K., 1971 - "B" chromosome bei Chironomus. Chromosoma, 35: 402-407.

Keyl H. and Keyl I., 1959 - Die cytologische Diagnostik der Chironomidae. I. Bestimmungstabelle fur die Gattung Chironomus auf Grund der Speicheldrusen - Chromosomen. Arch. Hydrobiol., 56: 43-57 (1959).

Kiknadze I.I., Butler G.M., Aimanova K.G., AnDreeva E., Martin J., and Gunderina L., 1998 Divergent cytogenetic evolution in Nearctic and Palearctic populations of sibling species in Chironomus (Camptochironomus) Kieffer. Can. J. Zool., 76: 361 367.

Kiknadze I.I., Istomona A., Gunderina L., Salova T., Aimanova K. and Savinov D., 1996 - Karyofunds Chironomid Jacutij. A. Grusdev (ed). pp. 1-166 Novosibirsk, Nauka, (In Russian).

Kiknadze I.I., Shilova A., Kerkis I., Shobanov N., Zelentzov N., Grebenjuk N., Istomina A. and PRASlOv B., 1991a - Karyotype and morphology of larvae in Chironomini. Atlas. Nauka, Novosibirsk. 1-117 (In Russian).

Kiknadze I.I., Sitrin M., Filippova M., Gunderina L. and KalaChiKov S., 1991b - The change of the pericentric beterochromatin mass is one of important way of chironomid evolution. Tsitologya, 33:90-98. (In Russian).

Kownacki A., 1999. - Chironomidae. Checklist of macroinvertebrates in the river Visla. Acta bydrobiol., 37:41-75.

Michailova P., 1989 - The polytene chromosomes and their significance to the systematics of the family Chironomidae, Diptera. Acta Zool. Fenn., 186: 1-107.

Michailova P., 2001 - Cytogenetic characteristics of species of the Chironomus plumosus group (Chironomidae, Diptera) in Finland. Cytobios, 105: 99-114. 
Michailova P. and Fisher J., 1986 - Speciation within the plumosus group of the genusn Chironomus Meigen (Diptera, Chironomidae). Zeit. für zool. Systematik und Evolutionsforschung, 24: 207 222.

Michailova P., Krastanov B. and Kownacki A., 2002 - Cytotaxonomical characteristics of genus Chironomus Meigen (Diptera: Chironomidae) from different localities of Poland. Annales Zoologici, 52: 215-225.

Michailova P. and Mettinen A., 2000 - Cytotaxonomical variability of Chironomus plumosus L. and C. anthracinus Zell. (Diptera, Chironomidae) from industrial and municipal polluted areas of Finland. Caryologia, 53: 69-81.

Michailova P. and Petrova N.,1991 - Chromosomal polymorphism in geograpbycally isolated populayions of Chironomus plumosus L. (Chironomidae, Diptera). Cytobios, 67: 161-175.

Michailova P., Petrova N., Ramella L., Sella G., Todorova J. and Zelano V., 1996 - Cytogenetic characteristics of a population of Chironomus riparius Meigen (Diptera, Chironomidae) from a polluted Piedmont station. Genetica, 98: 161-178.

Michailova P., Petrova N., Sella G., Ramella L. and Bovero S., 1998 - Structural-functional rearrangements in chromosome $G$ in Chironomus riparius Meigen (Diptera, Chironomidae) collected from a beavy metal polluted area near Turin, Italy. Environ. Poll., 103: 127-135.

Michailova P., Petrova N., Bovero S., Caviccioli O., Ramella L. and Sella G., 2000 - Effect of environmental pollution on the chromosome variability of Chironomus riparius Meigen 1804 (Diptera, Chironomidae) larvae from two polluted Piedmont stations. Genetica, 108: 171-180.

Michailova P., Warchałowska-Sliwa E. and KownACKI A., 2001 - Cytotaxonomic characteristics of the genus Glyptotendipes Kieffer (Chironomidae, Diptera) from fish and retention ponds (Silesia, southern Poland). Folia Biol., (Krakow) 49: 163173.
Multhoff G., Botzler C. and Issels R., 1998 - The role of heat shock proteins in the stimulation of an immune response. Biol. Chem., 379: 295-300.

NeI M., 1972 - Genetic distance between populations. Am. Nat., 106: 283-291.

Ollik M. and ZBikowski J., 2002 - Biometric of larvae of the genus Chironomus in Rybnik gravel pit lake. In: Proceeding of IX Polish Bentological workshop, Univ. Nicolai Copernici Torun-Bachotek 7 (In Polish).

Pederson B.V, 1978 - Comparison of the inversion polymorphism in three Danish populations of the midge Chironomus plumosus L. (Diptera, Chironomidae). Hereditas, 89: 151-162.

Petrova N., 1991 - Chromosomal rearrangements in three species of Chironomus (Diptera, Chironomidae) from the Chernobyl zone. Genetika, 27: 836848 (In Russian).

Petrova N. and Michailova P., 1986 - The population - karyological studies of some Chironomidae species (Diptera, Chironomidae). Tsitologya, 28:727734 (In Russian).

Ryser H. M., Scholl A. and Wulker W., 1983 - Revision der Gattung Chironomus Meigen (Diptera). VII. C. muratensis n.sp. und C. nudiventris n.sp. Geschwisterarten aus der plumosus Gruppe. Rev. Suisse Zool., 90: 299-316.

Sitrin M., Rubzov N., Karamisheva T., Katokhin A., Karagodin D. and Kiknadze I.I., $2003-M o-$ lecular cytogenetic characteristics of Chironomis " $B$ " chromosome (Diptera, Chironomidae). Tsitologya, 6:582-589 (In Russian).

Sneath P. and Sokal R., 1973 - Numerical Taxonomy. San Francisco: Freeman.

WIEslander L.,1994 — The Balbiani ring multigene family: coding sequences and evolution of a tissue specific function. Proc. Nucleic Acids res., 48: 275 313.

Received II.14.2005; accepted VII.07.2005 